Gut, 1964, 5, 295

\title{
Studies on the mechanism of destruction of the toxic action of wheat gluten in coeliac disease by crude papain
}

\author{
M. MESSER, CHARLOTTE M. ANDERSON, AND LOIS HUBBARD \\ From the Gastroenterological Research Unit, \\ Royal Children's Hospital Research Foundation, \\ Melbourne, Australia
}

EDITORIAL SYNOPSIS The toxic action of wheat gluten on two patients was eliminated after predigestion of gluten by crude papain. This change is thought to be due to an enzyme which liberates ammonia from gluten. It is not thought that this particular mechanism operates in the normal intestinal cell but it is envisaged that one of the peptide bonds of the coeliac active constituent (possibly a N-glutaminyl peptide) is normally split by a specific intestinal peptidase which is defective in coeliac patients.

Previous authors have shown that the harmful action of dietary wheat gluten in coeliac disease or non-tropical sprue is not eliminated by predigesting the gluten with either pancreatin or pepsin or trypsin (Alvey, Anderson, and Freeman, 1957; Frazer, Fletcher, Ross, Shaw, Sammons, and Schneider, 1959; Krainick, Mohn, and Fischer, 1959; van Roon, Haex, Seeder, and de Jong, 1960). Of various enzymes from animal sources, only an extract of hog intestinal mucosa has so far been shown to abolish the toxic action of gluten in coeliac disease (Frazer, 1956).

It has been reported, however (Krainick et al., 1959), that after wheat gluten has been digested by crude papain (a commercial product prepared from the latex of the unripe papaya) it is no longer harmful when fed to coeliac patients. This phenomenon has not been investigated further, and it is not known whether the 'detoxification' is caused by papain itself or by another enzyme contained in the crude product, such as chymopapain (Jansen and Balls, 1941) or an enzyme acting on peptides.

The present studies were undertaken in order to confirm and extend these results of Krainick et al. (1959), in the hope that knowledge of the mechanism of action of crude papain on gluten might yield information concerning the chemical structure of the coeliac-active constituent of the protein.

To this end we have conducted experiments in which gluten which had been predigested either by crude papain or by purified constituents of papaya latex (papain and chymopapain) was fed to three coeliac patients.

We have also carried out certain investigations into the chemical mechanism of the digestion of gluten by crude papain, concerned mainly with the question of the origin of the free ammonia which is formed during this digestion (Krainick et al., 1959). These investigations led to the discovery of a new enzyme contained in papaya latex which acts specifically on N-glutaminyl peptides (Messer, 1963); the possible role of this enzyme in the detoxification of gluten by crude papain was given special attention.

PATIENTS, METHODS, AND MATERIALS

COELIAC PATIENTS The methods used in the diagnosis of coeliac patients, the collection of their stools during feeding investigations, and the estimation of stool fat were the same as those described in previous papers (Anderson, Frazer, French, Gerrard, Sammons, and Smellie, 1952; Messer and Anderson, 1961). Enzymatic gluten digests were administered in three doses per day, either neat or mixed with milk. When the patients were on a gluten-containing diet, meals were prepared by the diet kitchen to contain about $9 \mathrm{~g}$. wheat gluten per day.

GLUTEN Gliadin-enriched wheat gluten was supplied by Barret's Food Co. Pty. Ltd., Melbourne, who state that it was prepared by stirring commercial dried gluten in $0.01 \mathrm{M}$ acetic acid, centrifuging, and precipitating the gluten from the supernatant solution with sodium chloride, followed by freeze-drying. Its amide content was $2 \cdot 76 \mathrm{mmoles}$ per gram dry weight. 
PEPTIDES L-Glutaminyl-L-asparagine was supplied by Dr. J. M. Swan, C.S.I.R.O., Melbourne, and L-glutaminyl L-leucine by Drs. G. Amiard and R. Heymes, RousselUclaf, Paris. Small amounts of the corresponding pyrrolidone carboxylyl peptides were prepared for use as chromatographic markers by heating the $\mathrm{N}$-glutaminyl peptides for 60 minutes at $100^{\circ} \mathrm{C}$. in $0.1 \mathrm{M}$ phosphate buffer, $p \mathrm{H} 8$ (Waelsch, 1952). Glycyl-L-glutamine was supplied by Dr. J. M. Swan. All other peptides were obtained from Mann Research Laboratories, New York.

ENZYMES Crude papain was obtained from E. Merck A.G., Darmstadt, and crude ficin and bromelin from Mann Research Laboratories; crystalline papain, pepsin, trypsin, and chymotrypsin were products of Sigma Chemical Co., St. Louis.

Semi-pure, non-crystalline chymopapain was prepared by the following modification of the method of Jansen and Balls (1941). Finely ground granular dried papaya latex (Wheeler and Huisking Pty. Ltd., London), 80 g., was stirred with $800 \mathrm{ml}$. water for 30 minutes. The suspension was centrifuged and the supernatant solution adjusted to $p \mathrm{H} 2.0$ and held at $37^{\circ} \mathrm{C}$. for 80 minutes. It was then centrifuged and the supernatant solution adjusted to $p \mathrm{H} 4.0$ and half saturated with sodium chloride. After centrifugation the clear supernatant solution was fully saturated with sodium chloride and adjusted to $p \mathrm{H} 2 \cdot 0$. It was stood in the refrigerator overnight and then centrifuged. The white precipitate was chymopapain (about $10 \mathrm{~g}$.). The main differences between this method and that of Jansen and Balls (1941) are the use of dried instead of fresh papaya latex as the starting product and the 80 -minute treatment at $p \mathrm{H} 2.0$ at $37^{\circ} \mathrm{C}$. This treatment was necessary in order to destroy all deamidase and glutamine cyclotransferase activities (see Discussion). The treatment also inactivated papain. The chief contaminant of our chymopapain is probably lysozyme (Ebata and Yasunobu, 1962).

The activities of the crude papain, chymopapain, and crystalline papain towards benzoyl arginine amide were measured at $25^{\circ} \mathrm{C}$., $p \mathrm{H} 7.2$ in the presence of $5 \mathrm{mM}$ cysteine, $1 \mathrm{mM}$ ethylene diamine tetra-acetic acid (E.D.T.A.), and $50 \mathrm{mM}$ substrate. They were found to be $0 \cdot 40,0.33$, and $2 \cdot 7 \mu \mathrm{moles} / \mathrm{min} . / \mathrm{mg}$. enzyme protein, respectively.

\section{PREPARATION OF ENZYMATIC DIGESTS OF GLUTEN}

CRUDE PAPAIN DIGEST Crude papain, 40 g., was stirred for 30 minutes in 21 . cysteine $(10 \mathrm{mM})$ and E.D.T.A. $(2 \mathrm{mM}), p \mathrm{H} \mathrm{7 \cdot 5}$. The suspension was filtered and the filtrate, which contained about $20 \mathrm{~g}$. dissolved crude papain, was vigorously stirred by a magnetic bar while $100 \mathrm{~g}$. gluten was slowly sprinkled onto the surface; this procedure prevented the formation of lumps. During the addition of gluten the $p \mathrm{H}$ was maintained above 5.5 by dropwise additions of $5 \mathrm{M} \mathrm{NaOH}$ solution. Thirty minutes after all the gluten had been added the mixture was adjusted to $p \mathrm{H} 5.5$ and poured into a 51 . flask together with 21 . water and $40 \mathrm{ml}$. toluene. The flask was placed in a large bath kept at $37^{\circ} \mathrm{C}$. and the mixture stirred continuously by a magnetic bar for 42 hours. The digest was then filtered and the clear, orange filtrate adjusted to $p \mathrm{H} 10$ and evaporated in vacuo at $37^{\circ} \mathrm{C}$. to a volume of $1 \mathrm{l}$. by means of a rotary evaporator. The dark orange ammonia- and toluene-free product was adjusted to $p \mathrm{H} 6 \cdot 5$, filtered and stored at $-20^{\circ} \mathrm{C}$. until use.

The total amount of insoluble material (mainly lipid) removed during the procedure was about $5 \mathrm{~g}$.; the final product was therefore about $9.5 \%$ with respect to digested gluten.

CRYSTALline PAPAIN DIGEST This was prepared in the same way, except that $2 \mathrm{~g}$. crystalline papain was used per $100 \mathrm{~g}$. gluten. The final product was yellow.

CHYMOPAPAIN DIGEST Since native gluten was found to be digested by chymopapain with great difficulty, it was predigested by pepsin; $1 \mathrm{~g}$. crystalline pepsin was dissolved in 21 . cysteine $(5 \mathrm{mM})$ and E.D.T.A. $(1 \mathrm{mM}), p \mathrm{H} 2 \cdot 0$, and $100 \mathrm{~g}$. gluten was added. After two hours' stirring the mixture had become homogeneous and was adjusted to $\mathrm{pH} 5 \cdot 5$. Cysteine $(5 \mathrm{mM})$, and E.D.T.A. (1 $\mathrm{mM})$, pH 5.5, 21 ., containing $10 \mathrm{~g}$. dissolved chymopapain, was added and the mixture readjusted to $p \mathrm{H} 5 \cdot 5$. The rest of the procedure was as described for crude papain. The final product was orange.

Measurements of the formation of ninhydrin-reactive material showed that under the above conditions the digestion was over $90 \%$ complete in each case.

OTHER METHODS The amide content of gluten and of gluten digests was estimated by alkaline hydrolysis at room temperature (Stegemann, 1958).

Enzyme protein was determined by the biuret method described by Aldridge (1957).

Free ammonia and ninhydrin-reactive material in the gluten digests were estimated as follows. Of the digest, $0.10 \mathrm{ml}$. was treated with $0.1 \mathrm{ml}$. saturated $\mathrm{K}_{2} \mathrm{CO}_{3}$ solution in the outer well of a Conway microdiffusion unit and the ammonia liberated into $1.00 \mathrm{ml} .0 \cdot 1 \mathrm{~N}$ sulphuric acid. After 60 minutes the acid was analysed for ammonia (Brown, Duda, Korkes, and Handler, 1957) and the contents of the outer well diluted to $25.0 \mathrm{ml}$. and analysed for ninhydrin-reactive material by the method of Cocking and Yemm (1954). Standard mixtures of ammonium chloride and leucine were run through the whole procedure.

Paper chromatography (descending) was carried out on Whatman no. 1 paper with the following solvent systems; n-butanol : acetic acid : water (4:1:1), s-butanol: t-butanol : 2-butanone : water $(4: 4: 8: 5)$ and propanol: water $(4: 1)$. For two-dimensional chromatography the first two systems were used (Ambe and Tappel, 1961).

\section{RESULTS OF FEEDING INVESTIGATIONS WITH COELIAC PATIENTS}

PATIENT 1 This boy had been diagnosed as suffering from coeliac disease at the age of 13 months. Before that he had passed pale, bulky stools for several months and his abdomen had become distended. Investigations revealed marked steatorrhoea, microcytic anaemia, and a flat duodenal mucosa. He responded very well to a 


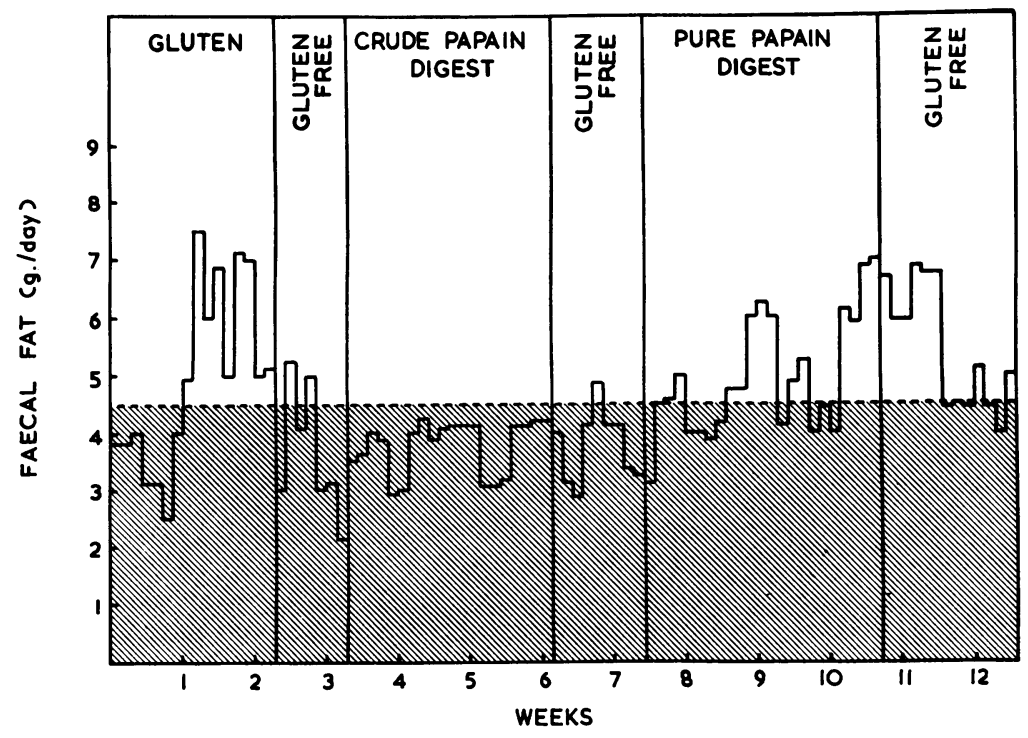

FIG. 1. Effects of feeding wheat gluten predigested by crude and pure papain on the daily excretion of fat (threeday mean) of patient 1 . The daily fat intake averaged $45 \mathrm{~g}$. Dotted line corresponds to upper limit of normal faecal fat (4.5 g. per day).

gluten-free diet. After some months he was readmitted and gluten was added to his diet; after nine days he developed steatorrhoea (Fig. 1). When the steatorrhoea had subsided again on a gluten-free diet the patient was fed daily $9 \mathrm{~g}$. of gluten which had been predigested by crude papain, his diet containing no other gluten. During the three weeks on this diet no steatorrhoea or other symptoms of coeliac disease were observed. The patient was then fed $9 \mathrm{~g}$. per day of gluten which had been predigested by crystalline (pure) papain; within 11 days his stools became pale, bulky, and soft, and showed marked steatorrhoea (Fig. 1). This feeding was stopped after three weeks, whereupon the patient's stools gradually returned to normality during the following period.

These results show that this patient reacted unfavourably to gluten predigested by pure papain but not to that predigested by crude papain.

PATIENT 2 This patient was a pale, fair-haired boy of 10 months who had failed to thrive in the preceding three months and had developed during the same time loose, pale, frequent stools and a distended abdomen.

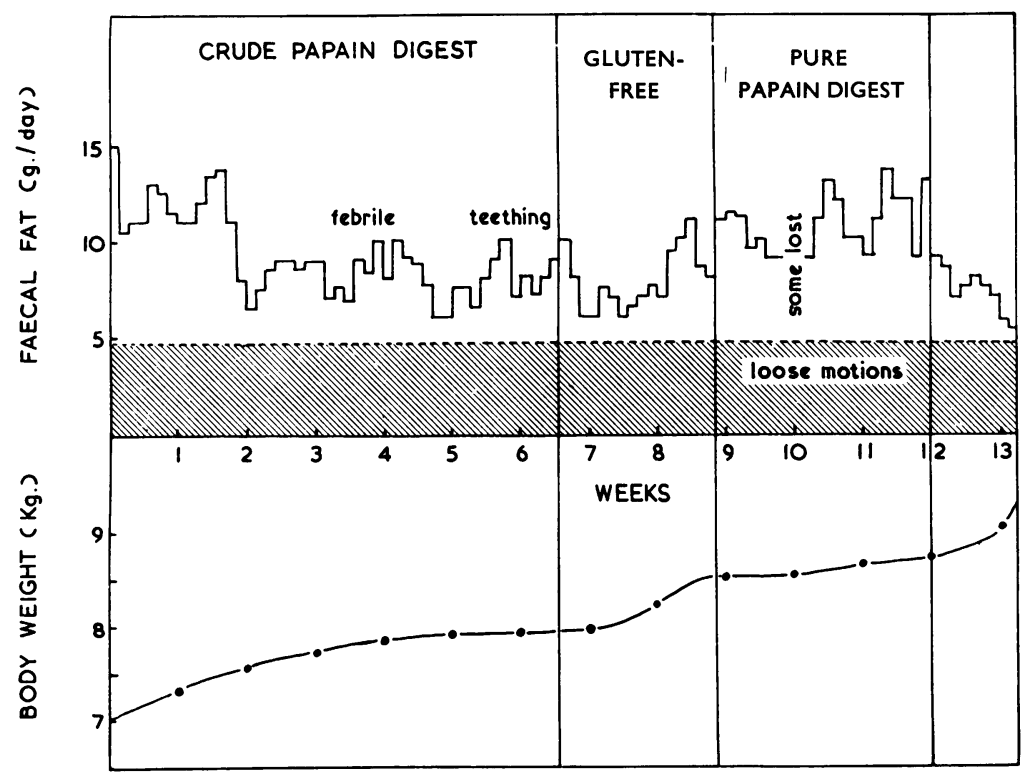

FIG. 2. Effects of feeding wheat gluten predigested by crude and pure papain on the body weight and daily excretion of fat (three-day mean) of patient 2. The daily fat intake averaged $45 \mathrm{~g}$. Dotted line corresponds to upper limit of normal faecal fat ( $4.5 \mathrm{~g}$. per day). 


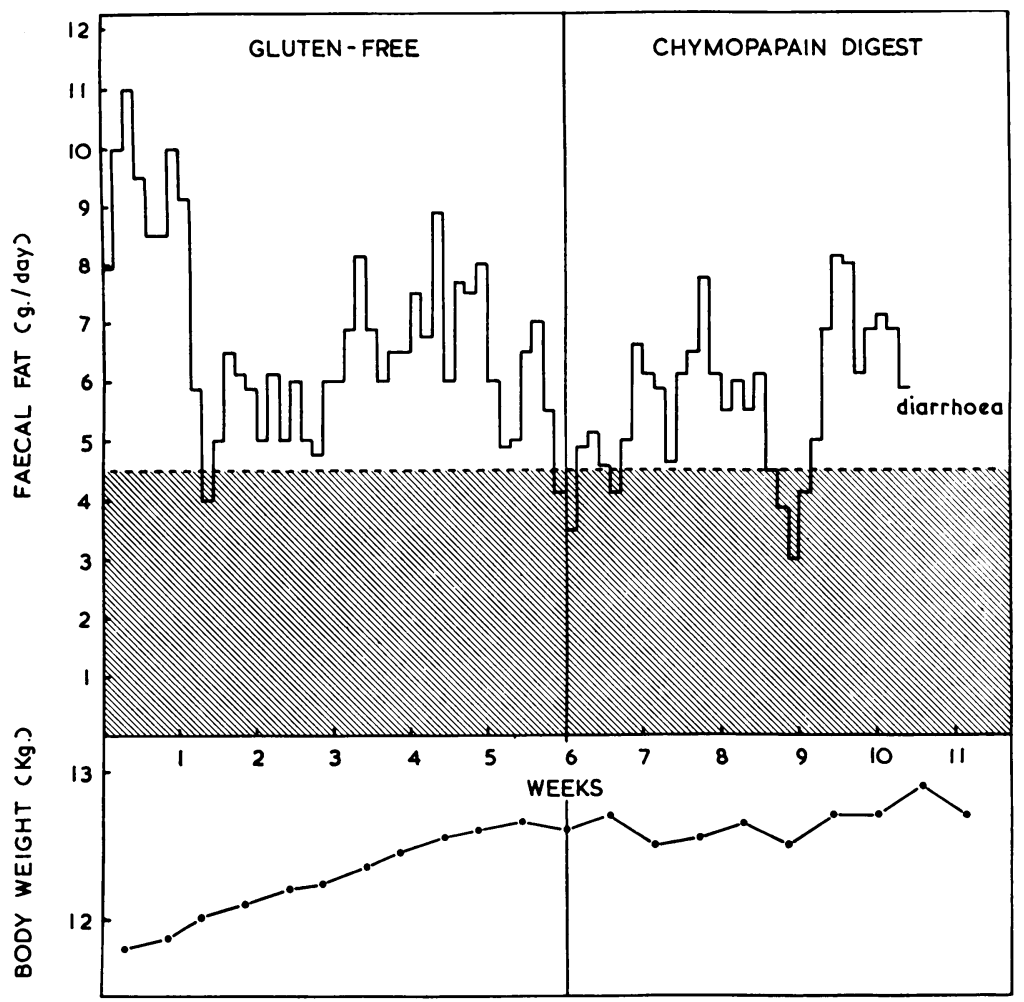

FIG. 3. Effects of feeding wheat gluten predigested by chymopapain on the body weight and daily excretion of fat (three-day mean) of patient 3. The fat intake averaged $40 \mathrm{~g}$. per day. Stool collections were incomplete so results were not recorded during the period of diarrhoea.

He had steatorrhoea (average of $13 \mathrm{~g}$. stool fat per day), mild microcytic anaemia, and a flat duodenal mucosa. He was placed on a gluten-free diet and also fed $6 \mathrm{~g}$. per day of the crude papain-digested gluten (Fig. 2). During the succeeding six weeks he improved considerably clinically, gaining $2 \cdot 3 \mathrm{~kg}$. despite an attack of otitis media and severe teething troubles. However, although the degree of steatorrhoea progressively lessened it did not disappear, an average of about $7 \mathrm{~g}$. fat being excreted per day. The crude papain digest was then stopped and after a gap of two weeks, during which the fat in his stools remained the same, the patient was fed $6 \mathrm{~g}$. per day of crystalline papain digest (Fig. 2). After eight days the stools became more bulky, loose and pale, and their fat content increased to an average of $11 \mathrm{~g}$. per day. The patient's weight fluctuated but overall was stationary during this feeding. The crystalline papain digest was stopped after three weeks; the child then gained weight and was allowed to go home. He continued to gain weight and made a good response to a gluten-free diet at home.

It was felt that the crude papain digest of gluten was not deleterious to this child because he continued to gain weight and his steatorrhoea decreased even in the presence of quite severe secondary infections. The crystalline papain digest, however, had a considerable deleterious effect clinically and on his degree of steatorrhoea.
PATIENT 3 This boy was admitted at the age of $2 \frac{1}{2}$ years, severely ill with symptoms and signs of coeliac disease, including failure to gain weight, very loose, creamy stools, marked temperamental difficulties, and a distended abdomen. Steatorrhoea and the flat pattern of the duodenal mucosa were demonstrated. The patient was in a state of 'coeliac crisis' for some days, and thereafter made a sure but slow response to a gluten-free diet, two months elapsing before his stools approached normality; they remained rather soft and pale. As we were unable to detain this child for much longer in hospital, he was given $7 \mathrm{~g}$. per day of chymopapaindigested gluten at this stage when his stools had not quite attained a normal fat content (Fig. 3). During the 31 days on this digest no gross change in his clinical condition was observed, but in comparison with the previous period the steatorrhoea did not continue to improve and his weight gain, which had been fairly satisfactory before the chymopapain-digested gluten had been given, became slow and irregular (Fig. 3). After three weeks on this digest the stools became quite fluid and creamy and the stool collections were incomplete.

It was felt that this patient reacted unfavourably to the chymopapain-digested gluten, though the response was not very marked and therefore not absolutely conclusive. Hence we prefer to maintain an open mind about the coeliac activity of the chymopapain-digested gluten. 
Unfortunately no further patients were available at this stage for long-term fat balance and feeding studies.

Table I summarizes our results concerning the toxicity or otherwise of the gluten digests with the foregoing three patients.

\section{TABLE I}

SUMMARY OF RESULTS OF EXPERIMENTS WITH WHEAT GLUTEN PREDIGESTED BY PAPAYA LATEX ENZYMES FED TO COELIAC PATIENTS

\begin{tabular}{clll} 
Patient No. & $\begin{array}{l}\text { Crude Papain } \\
\text { Digest }\end{array}$ & $\begin{array}{l}\text { Pure Papain } \\
\text { Digest }\end{array}$ & $\begin{array}{l}\text { Chymopapain } \\
\text { Digest }\end{array}$ \\
\hline 1 & Non-toxic & Toxic & - \\
2 & Non-toxic & Toxic & - \\
3 & - & - & Toxic (?)
\end{tabular}

\section{CHEMICAL STUDIES}

The general purpose of these studies was to determine whether crude papain contains an enzyme, other than papain and chymopapain, which could be responsible for destroying the coeliac activity of wheat gluten. As it turned out the investigation became concerned mainly with whether crude papain contains a deamidase. Krainick et al. (1959) had observed the liberation of a relatively large amount of free ammonia from gluten by crude papain, and Damodaran and Ananta-Narayanan (1938), who had made a similar observation with other proteins, had in fact postulated that papain contains a deamidase. In view of the evidence of van de Kamer and Weijers (1955) that glutamide amide might play a role in the coeliac activity of gluten, these observations seemed to us to be highly relevant. In addition to this question of deamidase activity of crude papain, we gave some attention to the possible role of specific peptidases in the gluten- 'detoxifying' action of crude papain; this aspect had been stressed by Krainick et al. (1959).

RELATIVE DEGREE OF DIGESTION OF GLUTEN BY VARIOUS PROTEASES It was of interest to compare the degree of digestion of gluten by a number of proteolytic enzymes. To this end we measured the amount of ninhydrin-reactive material, i.e., amino-acids and peptides with free alpha-amino groups, formed in each case during the digestion of the protein.

It was found that the plant enzymes used (papain, chymopapain, ficin, and bromelin) liberated much more ninhydrin-reactive material than did any of the animal proteases (Table II). It is evident that the former produce a considerably greater degree of digestion of the protein.

It is also noteworthy that appreciably less ninhydrin-reactive material was produced by crude papain than by either pure papain or chymopapain,
TABLE II

FORMATION OF NINHYDRIN-REACTIVE MATERIAL AND OF AMMONIA DURING DIGESTION OF WHEAT GLUTEN BY PROTEOLYTIC ENZYMES

Enzyme

\begin{tabular}{|c|c|c|c|}
\hline $\begin{array}{l}\text { Amount } \\
\text { (mg./g. } \\
\text { gluten) }\end{array}$ & $\mathrm{p} H$ & $\begin{array}{l}\text { Ninhydrin- } \\
\text { reactive Material } \\
\text { (leucine } \\
\text { equivalents, } \\
\text { excluding } \\
\text { ammonia) } \\
\text { (mmoles/g. gluten) }\end{array}$ & $\begin{array}{l}\text { Ammonia } \\
\text { (mmoles/g. } \\
\text { gluten) } \\
\end{array}$ \\
\hline
\end{tabular}

Crude papain
Crystalline papain
Chymopapain
Crude ficin
Bromelin
Crystalline pepsin
Crystalline trypsin
Crystalline chymo-
$\quad$ trypsin

$\begin{array}{rlll}200 & 5.5 & 1.42 & 1.28 \\ 20 & 5.5 & 1.78 & 0.12 \\ 100 & 5.5 & 1.60 & 0.11 \\ 200 & 6 & 1.91 & 0.34 \\ 200 & 6 & 1.55 & 0.14 \\ 20 & 2 & 0.44 & 0.16 \\ 20 & 8 & 0.27 & 0.08 \\ 20 & 8 & 0.77 & 0.07\end{array}$

${ }^{1}$ Chymopapain and trypsin were added after two hours' predigestion by pepsin.

Digestion by trypsin and chymotrypsin was done in the presence of $10 \mathrm{mM} \mathrm{CaCl}$, by the plant enzymes in the presence of $5 \mathrm{mM}$ cysteine and $1 \mathrm{mM}$ E.D.T.A. Crude papain, ficin, and bromelin were dialysed against $1 \mathrm{mM}$ E.D.T.A. before use. All digestions were done over 42 hours at $37^{\circ} \mathrm{C}$. in a volume of $40 \mathrm{ml}$. per g. gluten; toluene was added as preservative. Figures are corrected for moisture content of gluten and for ninhydrin-reactive material and ammonia formed in the absence of gluten.

despite the fact that crude papain contains a mixture of these two enzymes.

AMMONIA FORMATION DURING THE ACTION OF PROTEASES ON GLUTEN Table II shows that whereas a large amount of free ammonia was produced during the action of crude papain on wheat gluten, relatively little was produced by other proteolytic enzymes, including two constituents of crude papain (papain and chymopapain) and two other plant proteases (ficin and bromelin).

Determination of the total amide content of the digest showed that the crude papain had produced a decrease in amide-nitrogen equal to the increase in ammonia-nitrogen $(1.28 \mathrm{mmoles} / \mathrm{g}$.). Therefore the ammonia liberated by crude papain was derived from the amide groups of gluten; it represented $46 \%$ of the total amide content.

During early experiments with chymopapain it was found that unless the enzyme had been treated at $p \mathrm{H} 2$ at $37^{\circ} \mathrm{C}$. for at least 80 minutes, up to 0.8 mmoles of ammonia per gram gluten was produced during its action on gluten.

These results suggest that crude papain contains a deamidase which is distinct from both papain and chymopapain and is unstable at $p \mathrm{H} \mathrm{2}$. None of the other proteases tried, with the possible exception of ficin, had deamidase activity.

ACTION OF CRUDE PAPAIN ON GLUTAMINE AND ON GLUTAMINE PEPTIDES In order to elucidate the 
mechanism of the above-mentioned deamidase activity of crude papain, further investigations with this end in view were carried out. Since gluten has a very high glutamine content (about $40 \%$ ) it seemed that a possible mechanism was the deamidation of free glutamine formed as an intermediate during the course of the digestion. It was found, however, that both L- and D-glutamine remained largely unchanged when incubated with crude papain under the conditions which had been used for the digestion of gluten $\left(42\right.$ hours at $37^{\circ} \mathrm{C}$. at $p \mathrm{H} 5.5$ in the presence of $5 \mathrm{mM}$ cysteine and $1 \mathrm{mM}$ E.D.T.A.). Furthermore, paper chromatography showed that only small amounts of glutamic acid and pyrrolidone carboxylic acid (two possible products of the deamidation of glutamine) were present in the crude papain digest of gluten. No free glutamine could be detected.

It was considered that an alternative source of amide ammonia might be glutamine-containing peptides. When glycyl-L-glutamine was incubated with dialysed crude papain under the foregoing conditions, it remained largely unchanged. However, paper chromatography showed that two peptides in which L-glutamine occupies the $\mathrm{N}$-terminal position, viz., L-glutaminyl-L-asparagine and L-glutaminylL-leucine, completely disappeared in the presence of papain and were replaced by ninhydrin-unreactive products which had the same $R_{F} S$ in three different chromatographic solvent systems as pyrrolidone carboxyl-asparagine, and pyrrolidone carboxylylleucine, respectively (Table III). Estimation of the amide contents of the solutions showed that with both peptides an amount of ammonia equal (on a molar basis) to the amount of peptide initially present had been liberated. Neither of these changes were observed with pure papain or chymopapain, or after treatment of crude papain at $p \mathrm{H} 2$ at $37^{\circ} \mathrm{C}$. for 80 minutes.

\section{TABLE III}

$R_{F}$ VALUES OF NINHYDRIN-UNREACTIVE PRODUCTS OF ACTION OF CRUDE PAPAIN ON GLUTAMINYL PEPTIDES

\begin{tabular}{llll} 
& Solvent 1 & Solvent 2 & Solvent 3 \\
\hline L-glutaminyl-L-asparagine & 0.22 & 0.18 & 0.14 \\
L-glutaminyl-L-leucine & 0.81 & 0.49 & 0.55
\end{tabular}

Glutaminyl peptide, $25 \mu$ moles, was incubated with $5 \mathrm{mg}$. dialysed crude papain for $42 \mathrm{hr}$. at $37^{\circ} \mathrm{C}$. in a volume of $1 \mathrm{ml}$. in the presence of cysteine ( $5 \mathrm{mM}$ ) and E.D.T.A. ( $1 \mathrm{mM})$. At the end of this time all the glutaminyl peptide had disappeared. The above $R_{F}$ values are identical with those of pyrrolidone carboxylyl-L-asparagine and pyrrolidone carboxylyl-L-leucine, respectively.

Solvent 1: n-butanol:acetic acid:water, 4:1:1.

Solvent 2: s-butanol:t-butanol:2-butanone:water, $4: 4: 8: 5$.

Solvent 3: n-propanol:water, 4:1.
These results show that crude papain contains an enzyme, other than papain or chymopapain, which catalyses the cyclisation of N-glutaminyl peptides to the corresponding carboxyl peptides plus free ammonia and is unstable at $p \mathrm{H} 2$. Under the conditions used the enzyme had no effect on glutamine or on C-glutaminyl peptides.

FORMATION OF PYRROLIDONE CARBOXYLYL PEPTIDES DURING DIGESTION OF GLUTEN BY CRUDE PAPAIN The previous observations on the effect of crude papain on $\mathrm{N}$-glutaminyl peptides strongly suggested that the ammonia liberation from gluten by crude papain might be due to the action of the foregoing enzyme. In that case it should be possible to demonstrate the presence of pyrrolidone carboxylyl peptides in the digest.

This part of the investigation is incomplete but the following preliminary observation is noteworthy. A crude papain digest of gluten was dialysed and the dialysate subjected to paper electrophoresis in pyridine acetate buffer at $p \mathrm{H} 5 \cdot 7$. The negatively charged material was eluted and subjected to onedimensional paper chromatography in n-butanol: acetic acid:water $(4: 1: 1)$. It was found that three major and several minor spots stained with starchiodide following chlorination (Pan and Dutcher, 1956) but did not stain with ninhydrin. The $R_{F}$ values of the three major spots were $0 \cdot 13,0 \cdot 29$, and 0.38 respectively.

The observation suggests that the crude papain digest contained peptides which, being acidic and apparently lacking free alpha-amino groups, behaved like pyrrolidone carboxylyl peptides.

ACTION OF CRUDE PAPAIN ON OTHER PEPTIDES It was of interest to determine whether crude papain acts on peptides other than $\mathrm{N}$-glutaminyl peptides.

Samples of dialysed crude papain solution were incubated at $p \mathrm{H} 5.5$ and $37^{\circ} \mathrm{C}$. for 42 hours in the presence of $5 \mathrm{mM}$ cysteine and $1 \mathrm{mM}$ E.D.T.A. with the following peptides (each at $25 \mathrm{mM}$ ): glycylglycine, glycyl-L-proline, L-prolylglycine, glycyl-Lleucine, L-leucylglycine, L-leucinamide, L-alanylglycylglycine and carbobenzoxyglycyl-L-phenylalanine. These peptides are the main ones commonly used as substrates for the specific peptidases (Smith, 1951).

Paper chromatography showed that except for glycylglycine and the two proline peptides there was slight (less than 10\%) hydrolysis of all the peptides tried. Similar results were obtained, however, when pure papain was used instead of crude papain.

There was no hydrolysis of any peptide by crude papain in an E.D.T.A.-free medium containing $10 \mathrm{mM}$ iodoacetate (an inhibitor of papain and chymopapain). 
These results show that crude papain does not contain any of the common specific peptidases; in so far as there was any hydrolysis of peptides by crude papain, this could be ascribed to the actions of papain or chymopapain.

AMINO-ACID FORMATION DURING DIGESTION OF GLUTEN BY CRUDE PAPAIN According to Krainick et al. (1959), crude papain digestion of gluten results in the formation of appreciable amounts of free glutamine and proline.

The absence of free glutamine from a crude papain digest of gluten in the present studies has already been noted. Nor could free proline be detected, either by one- or two-dimensional paper chromatography.

No attempt was made to identify other aminoacids, but the probable presence of appreciable amounts of leucine (or isoleucine) was noted.

\section{DISCUSSION}

The results of the feeding investigations show that wheat gluten retains its harmful action on coeliac patients after digestion by pure (crystalline) papain but not after digestion by crude papain. The observation that crude papain destroys the coeliac activity of gluten had previously been made by Krainick et al. (1959). It is evident that crude papain contains a 'gluten-detoxifying' factor, presumably an enzyme, other than papain itself.

Papaya latex contains a variety of enzymes, including lipase, amylase, lysozyme, and others (Hwang and Ivy, 1951), but it can be assumed that the gluten-detoxifying enzyme is one acting on proteins or peptides.

Besides papain the only other protease known to be contained in papaya latex is chymopapain (Jansen and Balls, 1941 ; Ebata and Yasunobu, 1962). We tried to determine whether chymopapaindigested gluten retains its coeliac activity (patient 3 ), but unfortunately the result, though suggesting that the digest was still toxic, was not entirely conclusive. The possibility that the gluten-detoxifying enzyme is chymopapain therefore remains open.

Krainick et al. (1959) considered that the glutendetoxifying enzyme of crude papain might be a peptidase, but our results show that crude papain does not contain any of the known specific peptidases and has no action on peptides which could not be ascribed to papain itself.

It is conceivable that papaya latex contains other unknown proteases or peptidases, one of which might be the gluten-detoxifying enzyme, which split particular peptides formed as intermediates during the digestion of gluten. However, the only marked action which crude papain was found to have on peptides was the conversion of $\mathrm{N}$-glutaminyl peptides (L-glutaminyl-L-asparagine and Lglutaminyl-L-leucine) to the corresponding pyrrolidone carboxylyl peptides plus ammonia. This reaction was not observed with either pure papain or chymopapain and is therefore catalysed by an additional enzyme contained in crude papain. At the $p \mathrm{H}$ used for the crude papain digestion of gluten (5.5) this enzyme had no action on glutamine, but other investigations have shown that the analogous cyclisation of L-glutamine to ammonium pyrrolidone carboxylate occurs above $p H 7$ (Messer, 1963). This new enzyme has not yet been purified; we propose that for the time being it be called glutamine cyclotransferase.

Our results confirm the observation of Krainick et al. (1959) that crude papain liberates a large amount $(46 \%)$ of amide ammonia from gluten. Other proteases, including papain and chymopapain, liberated relatively minor amounts and it is evident that crude papain contains a deamidase distinct from these two enzymes. Damodaran and AnantaNarayanan (1938), on the basis of observations on ammonia liberation during the action of crude papain on casein and edestin, had previously postulated the presence of a deamidase in crude papain.

Both this deamidase and glutamine cyclotransferase were found to be unstable at $p \mathrm{H} 2$, and it seems highly probable that they are one and the same enzyme. This implies that the ammonia liberated from gluten by crude papain arises through the cyclisation of $\mathrm{N}$-glutaminyl peptides formed as intermediates in the digestion shown on page 302 .

This scheme could explain the observation that less ninhydrin-reactive material was produced during the digestion of gluten by crude papain than by pure papain or chymopapain (Table II), since pyrrolidone carboxylyl peptides, which have no free amino groups, would not be expected to react with ninhydrin.

The existence of glutamine cyclotransferase raises the possibility that this enzyme is the glutendetoxifying factor of crude papain, and that the coeliac-active constituent of gluten is therefore a $\mathrm{N}$-glutaminyl peptide. This idea is consistent with the fact that deamidation of gluten by means of hot dilute $\mathrm{HCl}$ has been shown to destroy its coeliac activity (van de Kamer and Weijers, 1955), indicating that its coeliac-active constituent must contain at least one glutamine residue. Before this could be considered to be more than a working hypothesis it would be necessary, however, to purify glutamine cyclotransferase and show that it has no action, e.g., proteolytic, other than on N-glutaminyl 
Gluten $\stackrel{\begin{array}{c}\text { Papain, } \\ \text { Chymopapain }\end{array}}{\longrightarrow}$<smiles>[R]OC(=O)CCCC(N)=O</smiles>

N-Glutaminyl peptides

plus

Other peptides, amino-acids

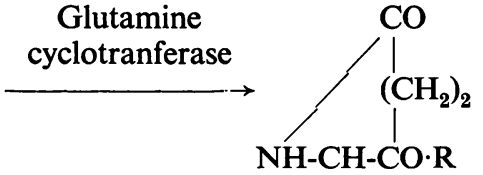

Pyrrolidone carboxyl peptides

plus

Ammonia

$\mathbf{R}=$ remainder of peptide

peptides. It would also be desirable to carry out further feeding investigations on coeliac patients with gluten which has been predigested by chymopapain or a combination of pure papain and chymopapain.

Several authors have postulated that the basic defect in coeliac disease involves an intestinal mucosal enzyme normally required to complete the intestinal digestion of gluten (see Frazer, 1962). Attempts to identify this enzyme with one of the known intestinal peptidases by comparing the actions of coeliac and non-coeliac duodenal mucosa on a number of simple peptides have yielded negative results (Messer, Anderson, and Townley, 1961). Therefore the postulated defective enzyme is probably one which acts specifically on an uncommon amino-acid sequence peculiar to gluten. The difficulty of testing this hypothesis has been that gluten consists of an infinite variety of aminoacid sequences any of which could conceivably be the coeliac-active constituent. The present results, which suggest that this constituent might be distinguished by having glutamine as its $\mathrm{N}$-terminal amino-acid, constitute a rationale for isolating or preparing $\mathrm{N}$-glutaminyl peptides contained in pure papain and chymopapain digests of gluten, and comparing their behaviour in the presence of coeliac and non-coeliac duodenal mucosa.

To avoid possible misunderstanding we wish to emphasize that we expect the 'gluten-detoxifying' mechanism of the normal intestine to be quite different from that of crude papain. There is no evidence, either for the occurrence of an enzyme like glutamine cyclotransferase in the intestinal mucosa, or for the deamidation of gluten or of peptides derived from gluten during normal digestion. We rather envisage that one of the peptide bonds of the coeliac-active constituent (possibly a $\mathrm{N}$-glutaminyl peptide) is normally split by a specific intestinal peptidase which is defective in coeliac patients.

Krainick et al. (1959) found that their crude papain digest of gluten contained appreciable amounts of free glutamine and proline, and therefore proposed that the coeliac-active constituent of gluten might be a glutamine-proline polypeptide which is normally 'detoxified' in the intestine by a peptidase such as prolidase. We were unable, however, to detect either glutamine or proline in the digest; the observation that the crude papain had no prolidase or prolinase activity was consistent with this. Furthermore, previous studies have shown that there is no difference between coeliac and non-coeliac duodenal mucosa in their prolidase or prolinase activities (Messer et al., 1961). It is nevertheless possible, as suggested by Krainick et al. (1959), that the postulated coeliac-active peptide consists mainly of glutamine and proline, if only for the reason that these two amino-acids together constitute over $50 \%$ of the protein (Woychik, Boundy, and Dimler, 1961). The apparent resistance of the coeliac-active constituent of gluten to a variety of proteases (pepsin, trypsin, pancreatin, pure papain, and probably also chymopapain) suggests that it has an unusual amino-acid composition; this could well be due to a high proline content.

\section{SUMMARY}

The toxic action of wheat gluten on two coeliac patients disappeared after predigestion of gluten by crude papain but not after digestion by crystalline (pure) papain. A similar experiment with chymopapain-digested gluten was not entirely conclusive, but suggested that it, too, had retained its coeliac activity.

Crude papain was found to contain an enzyme (deamidase) which liberates free ammonia from gluten. Evidence is presented suggesting that this enzyme is identical with one which catalyses the conversion of N-L-glutaminyl peptides to the corresponding pyrrolidone carboxylyl peptides plus ammonia. The enzyme has been named glutamine cyclotransferase. 
It is proposed that glutamine cyclotransferase might be the factor in crude papain which eliminates the coeliac activity of gluten, and that this activity might therefore be due to an amino-acid sequence (peptide) contained in gluten which has L-glutamine as its $\mathrm{N}$-terminal amino-acid.

We wish to thank Barret's Food Co. Pty. Ltd., Melbourne, for their generous gift of gliadin-enriched wheat gluten; Dr. J. M. Swan, C.S.I.R.O., Melbourne, for gifts of glycyl-L-glutamine and L-glutaminyl-L-asparagine; and Drs. G. Amiard and R. Heymes, Roussel-Uclaf, Paris, for a sample of L-glutaminyl-L-leucine.

We would also like to thank Professor E. C. Webb, Secretary, Standing Committee on Enzymes, for advice on the naming of glutamine cyclotransferase, and Dr. F. J. R. Hird, Department of Biochemistry, University of Melbourne, for his valuable advice and encouragement.

\section{REFERENCES}

Aldridge, W. N. (1957). Liver and brain mitochondria. Biochem. J., 67, 423-431.

Alvey, C., Anderson, C. M., and Freeman, M. (1957). Wheat gluten and coeliac disease. Arch. Dis. Childh., 32, 434-437.

Ambe, K. S., and Tappel, A. L. (1961). Improved separation of amino-acids with a new solvent system for two-dimensional paper chromatography. J. Chromatog., 5, 546-548.

Anderson, C. M., Frazer, A. C., French, J. M., Gerrard, J. W., Sammons, H. G., and Smellie, J. M. (1952). Coeliac disease: gastro-intestinal studies and the effect of dietary wheat flour. Lancet, 1, 836-842.

Brown, R. H., Duda, G. D., Korkes, S., and Handler, P. (1957). A colorimetric micromethod for determination of ammonia; the ammonia content of rat tissues and human plasma. Arch. Biochem., 66, 301-309.

Cocking, E. C., and Yemm, E. W. (1954). Estimation of amino-acids by ninhydrin. Biochem. J., 58, 12P.

Damodaran, M., and Ananta-Narayanan, P. (1938). Enzymatic proteolysis. I. Liberation of ammonia from proteins. Ibid., 32, 1877-1889.
Ebata, M., and Yasunobu, K. T. (1962). Chymopapain. I. Isolation, crystallization, and preliminary characterization. J. biol. Chem., 237, 1086-1094.

Frazer, A. C. (1956). Discussion on some problems of steatorrhoea and reduced stature: on the growth defect in coeliac disease. Proc. roy. Soc. Med., 49, 1009-1013.

- (1962). The malabsorption syndrome, with special reference to the effects of wheat gluten. Advanc. clin. Chem., 5, 69-106.

- Fletcher, R. F., Ross, C. A. C., Shaw, B., Sammons, H. G., and Schneider, R. (1959). Gluten-induced enteropathy. The effect of partially digested gluten. Lancet, 2, 252-255.

Hwang, K., and Ivy, A. C. (1951). A review of the literature on the potential therapeutic significance of papain. Ann. N.Y. Acad. Sci., 54, 161-207.

Jansen, E. F., and Balls, A. K. (1941). Chymopapain: a new crystalline proteinase from papaya latex. J. biol. Chem., 137, 459-460.

Krainick, H. G., and Mohn, G. (1959). Weitere Untersuchungen über den schädlichen Weizenmehleffekt bei der Cöliakie. 2. Die Wirkung der enzymatischen Abbauprodukte des Gliadin. Helv. paediat. Acta, 14, 124-140.

Messer, M. (1963). Enzymatic cyclization of L-glutamine and L-glutaminyl peptides. Nature (Lond.), 197, 1299.

- , and Anderson, C. M. (1961). Pancreatic carboxypeptidases A and B in coeliac disease. Clin. chim. Acta, 6, 276-280.

,-- and Townley, R. R. W. (1961). Peptidase activity of biopsies of the duodenal mucosa of children with and without coeliac disease. Ibid., 6, 768-775.

Pan, S. C., and Dutcher, J. D. (1956). Separation of acetylated neomycins B and C by paper chromatography. Analyt. Chem., $28,836-838$

Smith, E. L. (1951). The specificity of certain peptidases. Advanc. Enzymol., 12, 191-257.

Stegemann, H. (1958). Eine Mikrobestimmung von Amid-Stickstoff, speziell in Proteinen. Hoppe-Seylers Z. physiol. Chem., 312, 255-263.

van de Kamer, J. H., and Weijers, H. A. (1955). Coeliac disease. V. Some experiments on the cause of the harmful effect of wheat gliadin. Acta paediat. (Uppsala), 44, 465-469.

van Roon, J. H., Haex, A. J. C., Seeder, W. A., and Jong, J. de (1960). Clinical and biochemical analysis of gluten toxicity. I. Experientia (Basel), 16, 209.

Waelsch, H. (1952). Certain aspects of intermediary metabolism of glutamine, asparagine, and glutathione. Advanc. Enzymol., 13, 237-319.

Woychik, J. H., Boundy, J. A., and Dimler, R. J. (1961). Wheat gluten proteins. Amino-acid composition of proteins in wheat gluten. J. Agric. Food Chem., 9, 307-310. 